\title{
Dental trauma in contact sports
}

\author{
Traumatismos dentários em esportes de contato
}

Luísa Bandeira Pires Monteiro LOPES'

Joana Freire FERREIRA ${ }^{2}$

\section{ABSTRACT}

\section{Objective}

Investigate the prevalence of dental traumas in participants of two contact sports (Judo and Taekwondo) and characterise some related factors.

\section{Methods}

Cross-sectional pilot study of observational nature, conducted by observing and collecting data and information. The sample consisted of 60 individuals of both genders aged between 5 and 15 years old, participants of Judo or Taekwondo. The statistical analysis involved descriptive and inferential statistical measures.

\section{Results}

The prevalence of dental trauma in the studied sample was of 38,3\%, with the majority occurring outside the practice of sport (82,6\%). Only 4 children suffered trauma whilst playing their sport, corresponding to a prevalence of $6,67 \%$. In addition, all 4 cases pertained to the practice of Judo. The most affected teeth were the primary maxillary central incisors followed by the permanent maxillary central incisors, with only one injured tooth in most cases. The lips were the soft tissue with greatest number of registered traumatic lesions. A statistically significant relationship was observed between risk factors and the occurrence of trauma.

\section{Conclusion}

A high prevalence of dental trauma in the studied population was found. Despite no record of traumatic lesions in Taekwondo, this prevalence was particularly noticeable in Judo.

Indexing terms: Martial arts. Mouth protectors. Tooth injuries.

\section{RESUMO}

\section{Objetivo}

Investigar a prevalência de traumatismos dentários na população praticante de dois esportes de contacto (Judo e Taekwondo) e caraterizar alguns fatores associados.

\section{Métodos}

Estudo piloto transversal com carácter observacional, realizado com recurso a observação e registo de dados e informações. A amostra foi de 60 indivíduos com idades compreendidas entre os 5 e os 15 anos, de ambos os sexos, praticantes de Judo ou Taekwondo no Parque de Jogos $1^{\circ}$ de Maio - INATEL. A análise estatística envolveu medidas de estatística descritiva e estatística inferencial.

\section{Resultados}

A prevalência de traumatismos dentários na população em estudo foi de 38,3\%, em que a maioria ocorreu fora da prática desportiva (82,6\%). Apenas 4 crianças sofreram traumatismos durante a prática desportiva, correspondendo a uma prevalência de 6,67\%. 0 único esporte predisponente para o trauma neste estudo foi o Judo. Os dentes mais atingidos foram os incisivos centrais superiores decíduos seguidos dos incisivos centrais superiores definitivos, e a maioria das situações afetou apenas um dente. O lábio foi o tecido mole com maior número de lesões traumáticas registadas. O hábito de utilização de protetor oral teve frequência nula. Verificou-se relação estatisticamente significativa entre a ocorrência de trauma e os fatores de risco estudados.

\section{Conclusão}

Foi encontrada uma alta prevalência de traumatismos dentários na população estudada. Esta mostrou-se alta no Judo, no entanto no Taekwondo não houve qualquer registo de lesões traumáticas.

Termos de indexação: Artes marciais. Protetores bucais. Traumatismos dentários.

\footnotetext{
${ }^{1}$ Instituto Superior Ciências Saúde Egas Moniz, Departamento de Odontopediatria. Campus Universitário, Quinta da Granja, Monte de Caparica, 2829-511, Almada, Portugal. Correspondência para / Correspondence to: LBPM LOPES. E-mail: <luisabpmlopes@gmail.com>.

${ }^{2}$ Cirurgiã-dentista. Lisboa, Portugal.
} 


\section{INTRODUCTION}

Dental trauma is considered a public health problem, both due to its high prevalence and the impact it has on the life of who is affected ${ }^{1}$. Its occurrence can have serious consequences and be at the root of various problems, not just physical but also social, psychological, behavioural, functional, aesthetic and economic ${ }^{1-2}$.

Contact sports are one of the most common aetiological factors and are defined as sports in which there is physical interaction between players, in the sense of trying to stop the opposing player or team to win $^{3-8}$. Oral and maxillofacial lesions are therefore frequent amongst participants of such sports ${ }^{9}$.

In addition, there are physical risk factors, like excess overjet (more than $3 \mathrm{~mm}$ ) and inadequate lip coverage, that can contribute to a higher predisposition to traumatic dental lesions $\mathbf{s}^{6,10-11}$.

The aim of this assignment is to provide a perspective on dental trauma in a young population within the practice of two contact sports.

\section{METHODS}

The study was conducted at Parque de Jogos $1^{\circ}$ de Maio - INATEL, Lisbon, Portugal.

Cross-sectional pilot study of observational nature conducted at the gyms where Judo and Taekwondo classes took place. Sample of 60 individuals from both genders between the ages of 5 and 15 (year of birth 1999-2009), participants in a contact sport.

The study was carried out resorting to observation and direct and personal interviews with the participants and father/mother/legal guardian, from which the following data and information were collated: gender; date of birth; type of contact sport; dental trauma occurrence; circumstances regarding the dental trauma (outside or during sport practice, or both); area of incidence of trauma (dental and/or soft tissue); occlusion; risk factors (excess overjet of more than $3 \mathrm{~mm}$ and inadequate lip coverage); habits regarding the use of mouthguard and type of mouthguard; and orthodontic treatment (at the time of the study).

The observation was conducted in the location/ room where the sports training took place (with the presence of artificial lighting), with the subject standing up facing the observer, and the father/mother/legal guardian next to him or her.
The inadequate lip coverage was determined at the start of observation by visual inspection, before the child noticed he/she was being observed. An adequate coverage is defined as the full cover of the maxillary incisors at rest, whilst an inadequate lip coverage is an incomplete cover of the incisors at rest, with about $2 / 3$ being visible and exposed ${ }^{12-13}$

The excess overjet of more than $3 \mathrm{~mm}$ was evaluated centrally and visualising the space from the vestibular face of the most protruded mandibular incisor to the vestibular incisor cusp of the most protruded maxillary central incisor ${ }^{13-14}$.

The statistical analysis was performed with SPSS (Statistical Package for the Social Sciences) version 20.0 for Windows.

This analysis involved descriptive statistical measures (absolute and relative frequencies, means and standard deviations) and inferential statistics. In the latter, non-parametric statistics were used since our dependent variables are qualitative. The Chi-squared test of independence was used to test the relationship between qualitative variables. The hypothesis analysed was that no more than $20,0 \%$ of the cells had expected frequencies below 5 . When this hypothesis was not satisfied, the Monte Carlo simulation Chi-squared test was employed. The differences were examined with the support of adjusted standardised residuals. $\ln 2 \times 2$ tables $(g l=1)$, the Fisher test was used. The Binomial test was used to test the difference between two proportions.

The significance level was set as $(\boldsymbol{\alpha}) \leq 0.05$. However, any differences significant at a level of $(\alpha) \leq 0.10$ were duly commented.

\section{RESULTS}

Of the 60 children who participated in the study, most were male $(80.0 \%, \mathrm{n}=48)$, with females constituting the other $20.0 \%$ of the sample $(n=12)$. The mean age was 9.9 years ( $\mathrm{sd}=2.7$ years) and the mode was 9 years (20.0\%). The youngest subjects (5 years of age) represented $3.3 \%$ of the total and the oldest (15 years) $6.7 \%$. The same number of children doing Judo $(n=30)$ and Taekwondo $(n=30)$ were observed.

In total, traumas occurred in 23 children, corresponding to a prevalence of $38.3 \%$, with most of these $(82.6 \%)$ occurring outside the practice of sport. The prevalence of trauma during sport was $6.67 \%$, i.e. only 
4 children suffered traumatic lesions whilst playing their sport.

Of these 4 children, all of them did Judo; therefore, there was a higher occurrence of trauma associated with the practice of the martial art of Judo compared to the occurrence of trauma in the practice of Taekwondo (13.3\% vs $0.0 \%$ ) even though the difference is not statistically significant $(p=0.112)$ (Figure 1).

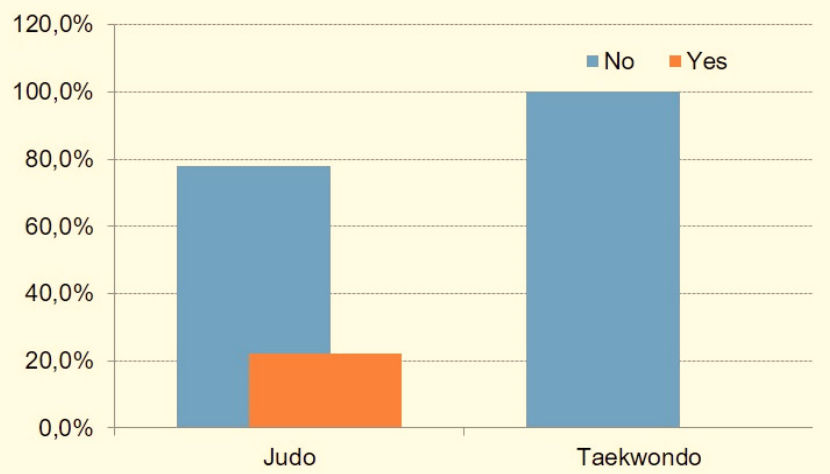

Figure 1. Occurrence of traumas in sport and sport breakdown.

It was detected that most dental traumas $(\mathrm{n}=$ 12) occurred in only one tooth. The teeth that carried the largest number of traumatic lesions were the primary maxillary central incisors (63.6\%), followed by the permanent maxillary central incisors (31.8\%) (Figure 2).

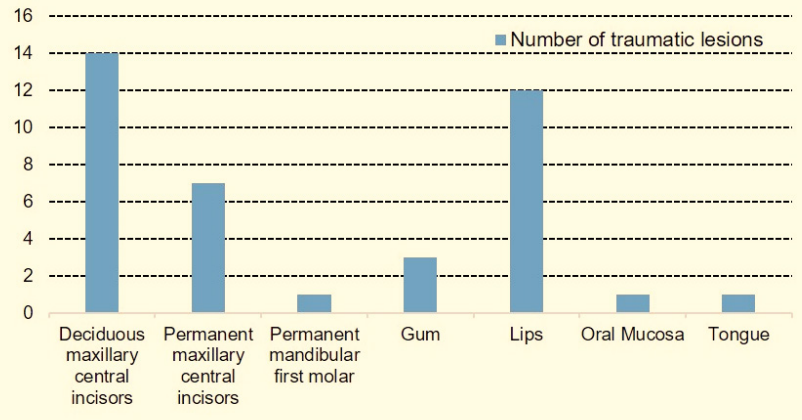

Figure 2 . Number of traumatic lesions (dental and/or soft tissue)

Soft tissue lesions occurred in 15 individuals $(25.0 \%)$, with the majority of these occurring only on the lips $(66.7 \%)$, followed by the gum. Combining teeth and soft tissue lesions, the most affected regions were thus the primary maxillary central incisors in first place and then the lips (Figure 2).
The majority of children did not present any risk factor $(93.3 \%)$ and that registering the highest occurrence was excess overjet (3.3\%).

For a significance level of $(\alpha) \leq 0.10$, the relationship between trauma occurrence and risk factors is statistically significant $(p=0.088)$. Children with the excess overjet risk factor registered higher occurrence of traumas (8.7\% vs $0 \%)$. All individuals with excess overjet or both risk factors suffered traumatic lesions, whereas no trauma was registered for the individual with only inadequate lip coverage. In children without any risk factors, the absence of traumas was higher than their presence (Figure 3).

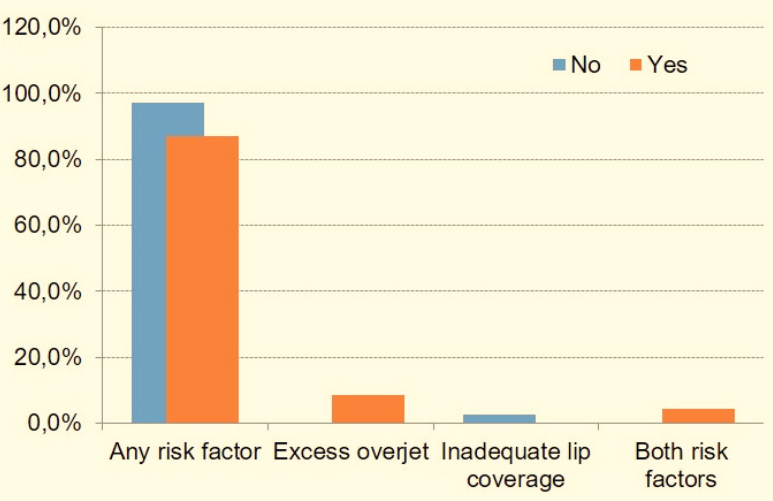

Figure 3 . Occurrence of trauma and risk factors.

The habit of using a mouthguard was nonexistent, since none of the children in either Judo or Taekwondo used it during the practice of their sport. Even so, 10 children indicated that they wore a helmet with visor whilst taking part in martial arts and they all did Taekwondo, representing $33.3 \%$ of those who played this sport.

There was a higher proportion of traumas in male compared to female children ( $41.7 \%$ vs $25.0 \%)$ although the difference was statistically insignificant $(p=0.340)$.

Considering the large range of ages of the sample, a subdivision of the ages under study was performed in order to conduct correlation analysis. Two groups were formed, one with ages between 5 and 10 years old and the other with individuals older than 10 years. The proportion of trauma was higher in children older than 10 years $(41.7 \%$ vs $36.1 \%)$ although the difference was statistically insignificant ( $p=0.788)$.

The occurrence of traumas is greatest in the bilateral class I (69.6\%) and lowest in the bilateral class III $(4.3 \%)$, despite the difference not being statistically significant $(p=0.242)$. 


\section{DISCUSSION}

The prevalence was defined as the percentage of children doing Judo and Taekwondo that suffered dental and soft tissue traumas during and outside the practice of their sport. It was $38.3 \%(n=23)$, which translates into a high prevalence. Various studies present wide-ranging values, from $4.15 \%$ to $44.2 \%^{1,11,13,15-20}$. This rate varies considerably between studies, since the methodology employed in each differs significantly. The type of study, classification of traumatic lesions, diagnosis criteria, age intervals, type of dentition and geographical location are all factors that affect results.

In this investigation, the prevalence of dental traumas found in children during the practice of their sport was $6.67 \%$, corresponding to 4 occurrences. Within the several mentioned studies, this value varies between $8.5 \%$ and $44.2 \% 9,21-25$. The resulting differences may be due to a number of factors. It must be considered that the sports evaluated in each study as well as age intervals vary between studies; this means they are not always the same and differ from those in this essay.

In this study, a relationship was found between dental and soft tissue traumas occurring whilst taking part in sport and the type of sport, with Judo being the only one with occurrences and Taekwondo having none.

All 4 occurrences happened in Judo, thus corresponding to a prevalence of $13.3 \%$ in this sport. Studies that relate to Judo present similar values, ranging from $2.7 \%$ to $22.3 \%{ }^{21,23,26}$.

With respect to Taekwondo the prevalence found was $0 \%$, differing from the results of all studies referenced in this essay; these put forward values varying between $16.7 \%$ and $17.3 \%^{9,22}$. Apart from the factors described above, this difference may be due to Taekwondo being a sport focusing on self-defence and to the conditions in which the athletes at the location of the study practice; i.e. the fact that only 10 out of the 30 young Taekwondo players participate in combats where there is direct physical contact may have limited the prevalence observed. Most of the younger athletes only perform combat moves individually, progressing to actual combats at an older age or after reaching a more advanced level. Of the 10 Taekwondo athletes (33.3\%) that already participated in direct contact combats, all wore a helmet with visor and other protection accessories, which may have also been an advantage in the protection of the oral cavity (teeth and soft tissues).

The majority of traumatic dental lesions occurred in the maxillary central incisors (primary and permanent) $)^{1,11-15,18-20,27-28}$. However, the primary teeth, specifically the primary maxillary central incisors (right or left), were the most affected by trauma. This result is identical to that achieved in the study by Chan et al. ${ }^{28}$ that includes both dentitions. This seems to be related to the start of development of motor skills and the accidents during this developmental stage ${ }^{28}$. Nonetheless, other studies that include both dentitions refer that, contrary to what this investigation reports, the teeth suffering most trauma were the permanent maxillary central incisors ${ }^{11,27}$.

The maxillary central incisors are the set of teeth most affected by trauma probably due to their earlier eruption, being predisposed to a longer exposure period ${ }^{1}$.

The dental traumas observed were found to occur predominantly in only one tooth $(n=12)$, in agreement with the literature $1,11,13,15,18,20$

In terms of soft tissue traumatic lesions, the most affected region was the lips, similarly to the results of the study by Chan et al. ${ }^{28}$.

The relationship between the studied risk factors and the occurrence of dental trauma is an extensively researched topic and this relationship was found to be statistically significant in this investigation. Many of the other studies also support the relationship between both risk factors and the presence of dental trauma ${ }^{11-12,15-16}$. Others mention that a relationship was not found or was not statistically significant in both cases $^{1,18}$. The study by Çetinbas et al. ${ }^{14}$ additionally tells us that there is a statistically significant relationship with respect to the overjet risk factor but not in the case of inadequate lip coverage; the results of this study support this finding, as a relationship between risk factors and the occurrence of trauma was found, particularly with regards to excess overjet.

Within the population participating in contact sports, the use of mouthguards was nonexistent $(0 \%)$.

The habit of using mouthguards whilst participating in sport varies considerably between studies, since they deal with different sports and competitive frameworks. Most of these put forward higher values than the one found in this study; even so, they consider the use of mouthguards, especially within martial arts, to be lower ${ }^{21,24,29}$. In addition, only two of the referenced studies obtained a figure of $0 \%$ with respect to the use of mouthguards ${ }^{14,23}$.

Even though the difference is not statistically significant, there is a higher proportion of traumas in children above 10 years of age compared to those below $10(p=0.788)$. The occurrence of dental traumas tends 
to increase with age, probably due to the more frequent participation in sport, as well as training and competitions

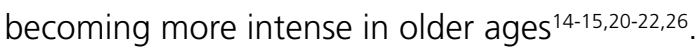

In this investigation most of the athletes were male $(80 \%)$. Furthermore, a relationship between the male gender and the occurrence of dental trauma was found, although similarly to other studies it was not statistically significant $(p=0.340)^{17}$. This may be related to a higher participation of boys in contact sports and more physically aggressive activities ${ }^{1}$.

\section{CONCLUSION}

Due to the high prevalence of dental traumas (including soft tissue lesions), preventative measures are

\section{REFERENCES}

1. Marinho AC, Manso MC, Colares V, Andrade DJ. Prevalência de traumatismo dentário e fatores associados em adolescentes no concelho do Porto. rev port Estomatol Med Dent Cir Maxilofac. 2013;54(3):143-9. doi: 10.1016/j.rpemd.2013.07.004

2. Emerich $\mathrm{K}$, Wyszkowski J. Clinical practice: dental trauma. Eur J Pediat. 2010;169(9):1045-50. doi: 10.1007/s00431-009-1130-x

3. Cornwell H. Dental trauma due to sport in the pediatric patient. J Calif Dent Assoc. 2005;33(6):457-61.

4. Guedes-Pinto A. Odontopediatria. São Paulo: Santos; 2010.

5. Boj JR, Catalá M, García-Ballesta C, Mendoza A, Plannels P. Odontopediatría: la evolución del niño al adulto joven. Madrid: Ripano; 2010.

6. Glendor U. Aetiology and risk factors related to traumatic dental injuries - a review of the literature. Dent Traumatol. 2009 Feb;25(1):19-31. doi: 10.1111/j.1600-9657.2008.00694.x

7. Newsome PRH, Tran DC, Cooke MS. The role of the mouthguard in the prevention of sports-related dental injuries: a review. Int J Paediatr Dent. 2001;11(6):396-404.

8. Verma L. Managing the challenge of sports related dental injuries in atheletic children: a case report. J Exercise Sci Physiot. 2011;7(1):64-7.

9. Shirani G, Motamedi MHK, Ashuri A, Eshkevari PS. Prevalence and patterns of combat sport related maxillofacial injuries. J Emerg Trauma Shock. 2010;3(4):314-7. doi: 10.4103/09742700.70744

10. Traebert J, Bittencourt DD, Peres KG, Peres MA, de Lacerda JT, Marcenes W. Aetiology and rates of treatment of traumatic dental injuries among 12-year-old school children in a town in southern Brazil. Dent Traumatol. 2006;22(4):173-8. doi: 10.1111/j.1600-9657.2006.00359.x

11. Gupta S, Kumar-Jindal S, Bansal M, Singla A. Prevalence of traumatic dental injuries and role of incisal overjet and inadequate essential. As such, the development of educational policies directed at parents, health professionals, students, teachers and coaches are central.

Apart from his or her role in the treatment of traumatic lesions, the Dentist has a crucial role to play in acting towards the prevention, awareness, education and information of the problem.

\section{Collaborators}

LBPM LOPES was responsible for the bibliographical research and writing of the article. JF FERREIRA was responsible for data collection and statistical treatment

lip coverage as risk factors among 4-15 years old government school children in Baddi-Barotiwala Area, Himachal Pradesh, India. Med Oral Patol Oral Cir Bucal. 2011;16(7):e960-e965. doi:10.4317/medoral.17265

12. Prabhu A, Rao AP, Govindarajan M, Reddy V, Krishnakumar $\mathrm{R}$, Kaliyamoorthy $\mathrm{S}$. Attributes of dental trauma in a school population with active sports involvement. Asian J Sports Med. 2013;4(3):190-4.

13. Chopra A, Lakhanpal M, Rao NC, Gupta N, Vashisth S. Traumatic dental injuries among 12-15-year-old-school children in Panchklua. Arch Trauma Res. 2014 Mar; 3(1): e18127. doi: 10.5812/atr.18127

14. Cetinbas T, Yildirim G, Sönmez $H$. The relationship between sports activities and permanent incisor crown fractures in a group of school children aged 7-9 and 11-13 in Ankara, Turkey. Dental Traumatol. 2008;24(5):532-536. doi: 10.1111/j.16009657.2008.00647.x

15. Cavalcanti AL, Bezerra PK, de Alencar CR, Moura C. Traumatic anterior dental injuries in 7- to 12-year-old Brazilian children. Dental Traumatol. 2009;25(2):198-202. doi: 10.1111/j.16009657.2008.00746.x

16. Robson F, Ramos-Jorge ML, Bendo CB, Vale MP, Paiva SM, Pordeus IA. Prevalence and determining factors of traumatic injuries to primary teeth in preschool children. Dent Traumatol. 2009 Feb;25(1):118-22. doi: 10.1111/j.1600-9657.2008.00725.x

17. Mota, L., Targino, A., Lima, M., Farias, J., Silva, A., Farias, F. (2011). Estudo do traumatismo dentário em escolares do município de João Pessoa, PB, Brasil. Pesqui Bras Odontopediatria Clín Integr. 2011;11(2):217-222.

18. Damé-Teixeira N, Alves LS, Susin C, Maltz M. Traumatic dental injury among 12-year-old South Brazilian schoolchildren: prevalence, severity, and risk indicators. Dent Traumatol. 2013 Feb;29(1):52-8. doi: 10.1111/j.1600-9657.2012.01124.x

19. Schuch HS, Goettems ML, Correa MB, Torriani DD, Demarco FF. Prevalence and treatment demand after traumatic dental injury in South Brazilian schoolchildren. Dent Traumatol. 2013 Aug;29(4):297-302. doi: 10.1111/edt.12003 
20. Chen $Z$, Si $Y$, Gong $Y$, Wang JG, Liu JX, He $Y$, He WP, Nan $Z$, Zhang $Y$. Traumatic dental injuries among 8-to-12-yearold schoolchildren in Pinggu District, Beijing, China, during 2012. Dent Traumatol. 2014 Oct;30(5):385-90. doi: 10.1111/ edt. 12110

21. Ferrari $\mathrm{CH}$, Ferreria de Mederios JM. Dental Trauma and level of information mouthguard use in different contact sports. Dent Traumatol. 2002 Jun;18(3):144-7. doi: 10.1034/j.16009657.2002.00017.x

22. Tulunoglu I, Ozbek M. Oral trauma, mouthguard awareness, and use in two contact sports in Turkey. Dent Traumatol. 2006 Oct;22(5):242-6. doi: 10.1111/j.1600-9657.2006.00386.x

23. Bastida E, Peron R, Queiroz A, Hayacibara M, Terada R. Prevalência do uso de protetores bucais em praticantes de artes marciais de um município do Paraná. Rev Bras Odontol. 2010;67(2):194-8

24. Biagi R, Cardarelli F, Butti AC, Salvato A. Sports-related dental injuries: knowledge of first aid and mouthguard use in a sample of Italian children and youngsters. Eur J Paediatr Dent. 2010 Jun;11(2):66-70

25. Cavalcanti A, dos Santos F, Peixoto L, Gonzaga A, Dias C, Xavier A. Ocorrência de injúrias orofaciais em praticantes de esportes de luta. Pesq Bras Odontop Clínica Integr. 2012;12(2):223-8. doi: 10.4034/PBOCI.2012.122.11
26. Kujala UM, Taimela S, Antti-Poika I, Orava S, Tuominem R, Myllynen P. Acute injuries in soccer, ice hockey, volleyball, basketball, judo, and karate: analysis of national registry data. BMJ. 1995;311(7018):1465-8.

27. Toprak ME, Tuna EB, Seymen F, Gençay K. Traumatic dental injuries in Turkish children, Istanbul. Dent Traumatol. 2014 Aug;30(4):280-4. doi: 10.1111/edt.12092

28. Chan YM, Williams S, Davidson LE, Drummond BK. Orofacial and dental trauma of young children in Dunedin, New Zealand. Dent Traumatol. 2011 Jun;27(3):199-202. doi: 10.1111/j.16009657.2011.00989.x

29. Keçeci AD1, Eroglu E, Baydar ML. Dental trauma incidence and mouthguard use in elite athletes in Turkey. Dent Traumatol. 2005 Apr;21(2):76-9. doi: 10.1111/j.1600-9657.2004.00302.x

Received on: 2/10/2016

Final version resubmitted on: 16/5/2017

Approved on: 18/7/2017 